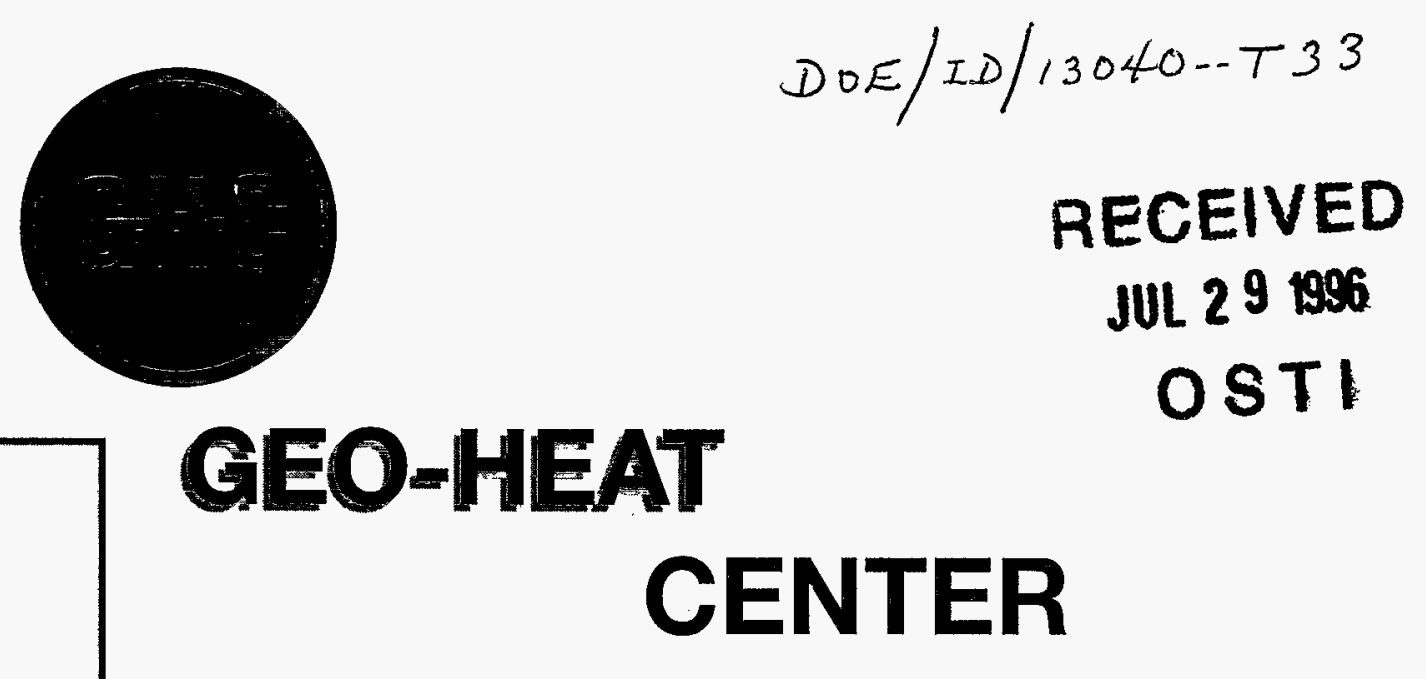

OREGON INSTITUTE OF TECHNOLOGY

A Geothermally Heated Campus

KLAMATH FALLS, OREGON 97601
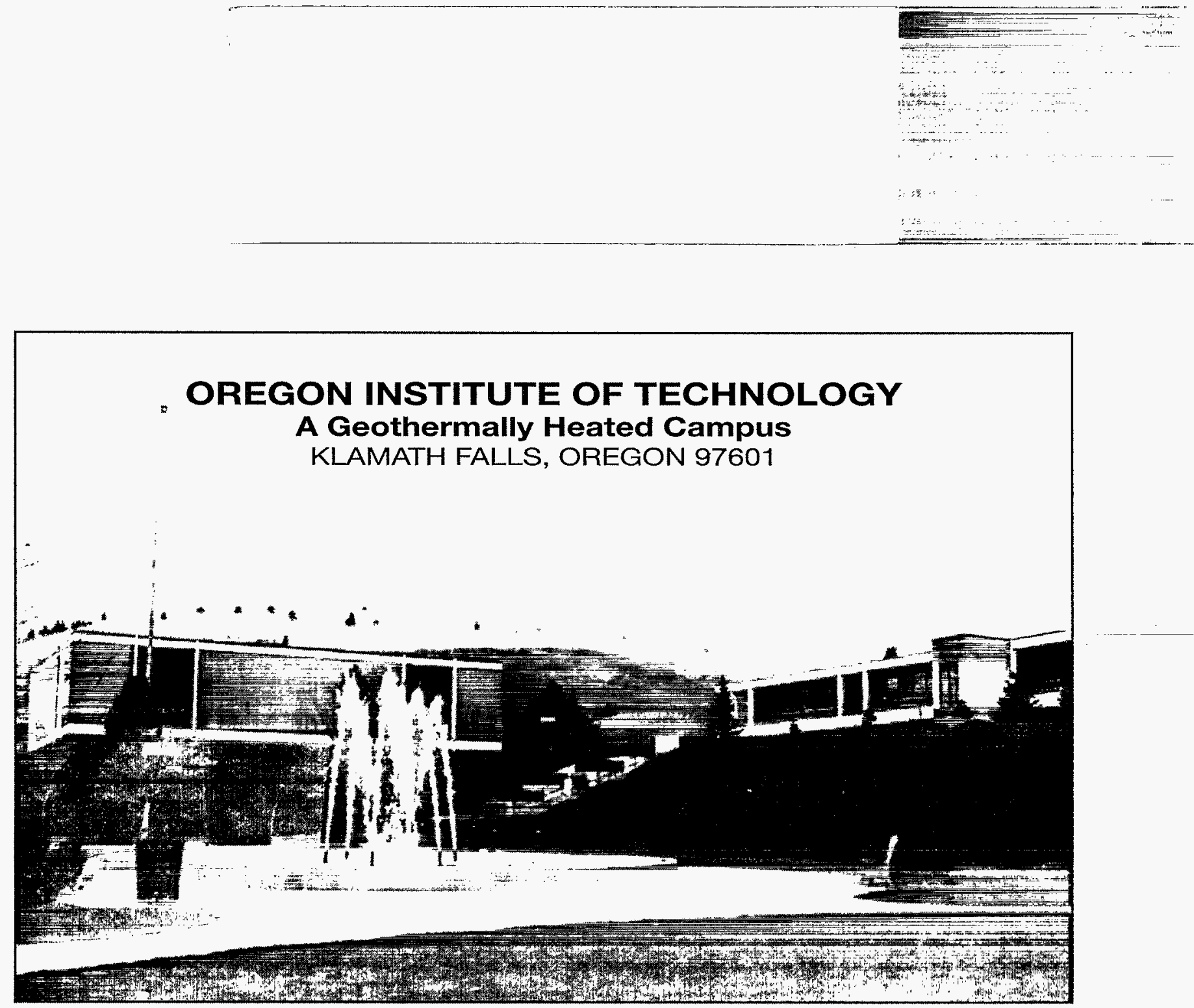


\title{
SELECTED COST CONSIDERATIONS FOR GEOTHERMAL DISTRICT HEATING IN EXISTING SINGLE-FAMILY RESIDENTIAL AREAS
}

\author{
Kevin Rafferty \\ June 1996
}

\section{DISCLAIMER}

This report was prepared as an account of work sponsored by an agency of the United States Government. Neither the United States Government nor any agency thereof, nor any of their employees, makes any warranty, express or implied, or assumes any legal liability or responsibility for the accuracy, completeness, or usefulness of any information, apparatus, product, or process disclosed, or represents that its use would not infringe privately owned rights. Reference herein to any specific commercial product, process, or service by trade name, trademark, manufacturer, or otherwise does not necessarily constitute or imply its endorsement, recommendation, or favoring by the United States Government or any agency thereof. The views and opinions of authors expressed herein do not necessarily state or reflect those of the United States Government or any agency thereof. 


\section{SELECTED COST CONSIDERATIONS FOR GEOTHERMAL DISTRICT HEATING IN EXISTING SINGLE-FAMILY RESIDENTIAL AREAS}

\section{EXECUTIVE SUMMARY}

In the past, district heating (geothermal or conventionally fueled) has not been widely applied to the single-family residential sector. Low-heat load density is the commonly cited reason for this. Although it's true that load density in these areas is much lower than for downtown business districts, other frequently overlooked factors may compensate for load density. In particular, costs for distribution system installation can be substantially lower in some residential areas due to a variety of factors. This reduced development cost may partially compensate for the reduced revenue resulting from low-load density.

This report examines cost associated with the overall design of the system (direct or indirectsystem design), distribution piping installation, and customer branch lines. It concludes with a comparison of the costs for system development and the revenue from an example residential area.

Distribution system installation costs were reviewed based on the use of double line (supply and return), preinsulated ductile iron piping. This material is currently the most widely used product for new distribution projects. Actual construction cost data was used along with cost calculations to disaggregate gross costs (\$/lf) into 11 individual areas for lines in the 3" to 12 " range. Each of these areas was then evaluated for potential cost savings. Among the savings identified were:

- Installation in unpaved areas can reduce costs $12 \%(12 ")$ to $22 \%(3 ")$,

- Uninsulated return lines use can reduce costs 9.3\% (3") and 8.9\% (4") based on the use of fiberglass in place of the preinsulated ductile iron,

- Elimination of active (flaggers) traffic control can reduce costs approximately $4 \%$ over the range of 3 " to 12 " lines, and

- Installation in areas unencumbered by existing buried utilities can reduce costs approximately $3.1 \%(12 ")$ to $3.9 \%(3 ")$.

The following figure presents cost data for 3", 6" and 12" lines sizes in graphical form. The base case costs are those identified in this study as being reflective of installation in downtown paved areas. The low case costs are those assuming that all of the above cost savings could be employed in a residential setting.

The substantial reduction in the smaller sizes is especially beneficial for single-family residential areas since a majority of the distribution system would be in the 3 " and 4 " size range. 


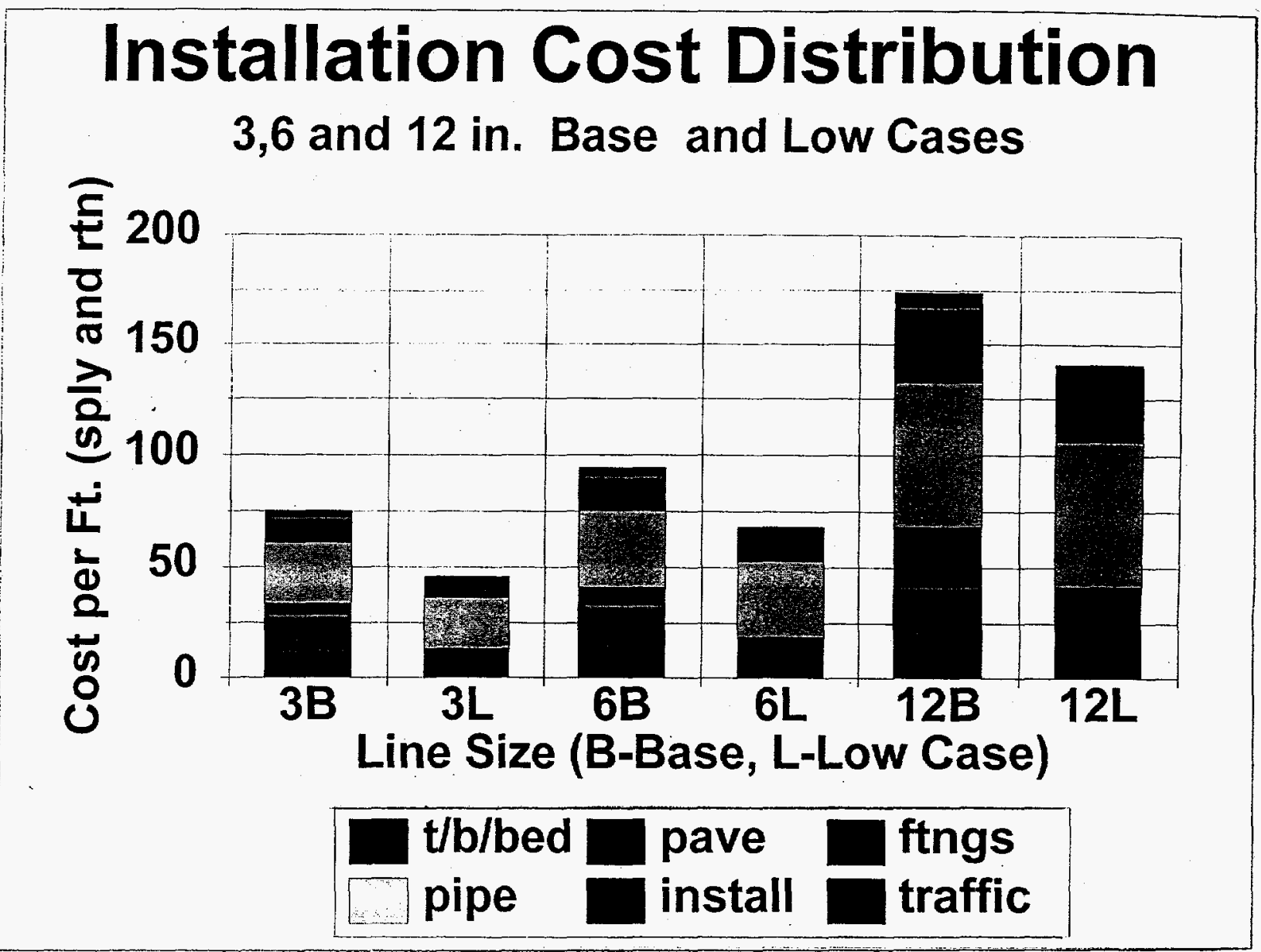

The location of heat exchangers between the geothermal fluid and the treated heating loop has an influence on system total cost. There are two general approaches: an indirect system in which central heat exchangers are used and only treated water is delivered to the customer, and the direct system in which geothermal fluid is delivered to the customer and individual heat exchangers are located at each user. Use of the central heat exchanger approach (indirect system) allows the elimination of additional equipment from the individual user residence. Due to the economy of scale, there is a point at which the cost of the central equipment is less than the sum of the costs for individual equipment at each user. Based on the assumptions used in this report, the central approach results in lower costs above system capacities of approximately $3,000,000$ $\mathrm{Btu} / \mathrm{hr}$ (approximately 40 homes $75,000 \mathrm{Btu} / \mathrm{hr}$ ).

Customer branch lines between the curb and the residence wall amount to a substantial expense to the homeowner when installed on a retrofit basis. Three types of piping for these branch lines were evaluated in this report: preinsulated copper, field-insulated copper and preinsulated flexible polyethylene (PEX). The preinsulated products have higher material cost but reduced field labor. The polyethylene product's flexibility can reduce fitting costs compared to copper. The results of calculations for this report (1" pipe size) suggest that the field-insulated copper is the lowest cost material at approximately $\$ 23 / \mathrm{ft}$ installed (supply and return), followed by $\$ 28 / \mathrm{ft}$ for the preinsulated copper and $\$ 31 / \mathrm{ft}$ for the polyethylene. At an average length of 60 feet per home, the cost of the branch lines would amount to approximately $\$ 1400$ per home using the field-insulated copper. 
In order to evaluate the overall feasibility of geothermal district heating, an actual residential area of Klamath Falls, Oregon, was used for analysis. This area is representative of many small-tomoderate sized western towns in which collocated resources have been found. An area of 16 blocks including 256 homes was selected. Costs were calculated for a complete system (construction costs only) including production wells, central plant, and distribution system. A range of costs for both the distribution system and the resource development was used. Resource development costs ranged from a single $500-\mathrm{ft}$ production well without injection to a system with two 2000-ft production wells and one 2000-ft injection well. Distribution costs used the current base case costs (downtown/paved) and low case costs (residential/unpaved). Table 12 summarizes this data.

Table 12

Expected Cost Range for 256 Homes GDH System

\begin{tabular}{|c|c|c|c|}
\hline & Low & & High \\
\hline Resource & $\$ 140,000$ & $\$$ & 540,000 \\
\hline Central plant & 225,000 & & 225,000 \\
\hline Distribution & 555,000 & & 803,000 \\
\hline & $\$ 920,000$ & & $, 568,000$ \\
\hline
\end{tabular}

Based on financing at $8 \%$ and a $75 \%$ customer connection rate, a revenue of between $\$ 452$ and $\$ 771$ per year per customer would be required to cover the system capital cost. Exisiting conventional space and domestic hot water heating costs in this area (6500 heating degree days, $1100 \mathrm{ft}^{2}$ average home size, primarily pre-1960 construction) ranges from a low of $\$ 440$ per year (all natural gas) to $\$ 1050$ per year (all electric).

This example suggests that for systems implemented with low-to-moderate cost resource and distribution costs, serving areas of propane, electric or fuel oil (or combinations of these with wood), that geothermal district heating can be possible. 


\section{INTRODUCTION}

District heating in existing single-family residential areas has long been considered to be uneconomical due to the low heating load density. In comparison to the typical downtown business districts load density is low; however, there are some characteristics of residential areas which could serve to enhance the economics of district heating.

Among these are:

- Wide variety of heating fuels (and costs) which can result in a range of conventional heating costs of 3 or more to 1 for the same heating load density,

- Availability of unpaved areas for installation of the distribution system,

- Fewer utilities in the pipeline corridor,

- Less traffic control requirements during construction,

- Potential for the use of uninsulated piping, and

- Older, poorly insulated structures with high energy use.

In addition to these considerations, the Geo-Heat Center has recently completed work which identified 271 western U.S. population centers which are collocated with geothermal resources of greater than $50^{\circ} \mathrm{C}$. In many of these sites, due to the allowance of industrial faciltieis, district heating would be the most useful application of the resource.

With these factors in mind, this report explores some of the issues related to costs involved in the installation of geothermal district heating $(\mathrm{GDH})$ in existing single-family residential areas.

Using an actual residential area as an example, individual sections of the report examine:

- Distribution piping costs and potential savings areas,

- Central plant vs. individual-home heat exchangers,

- Customer branch lines costs, and

- Current conventional heating costs vs. district system debt service revenue requirements. 


\section{DISTRIBUTION PIPING}

In order to evaluate the opportunities for cost reductions in distribution piping, it is first necessary to determine the costs associated with conventional construction. To accomplish this, costs from the most recent GDH construction (Klamath Falls city district system line extensions) were used as the basis for conventional construction.

Recent line extensions on this system and others have been of the 6 " size and employed preinsulated ductile iron material. Previous work (Rafferty, 1990) has identified this material as being the least expensive alternative among the preinsulated options for this type of application.

Bids on the recent Klamath Falls work are not broken down by task. As a result, costs for similar installation were calculated using vendor quotes and standard industry estimating handbooks (Means, 1995, 1996). The results of this comparison were quite close (calculated cost $\$ 94.51$ per foot, actual constuction $\$ 100$ per foot) with the calculated cost slightly less than the actual construction costs. This difference may be attributable to the relatively short length of the extensions compared to the size of a complete system. As a result of the close agreement, the same calculation method was used to develop costs for other line sizes in the 3 " to 12 " range. These calculations were then compared to the actual bid figures.

Costs for installation of preinsulated distribution piping were broken down into 11 categories: saw cutting of existing pavement, removal of pavement and trench spoils, hauling of pipe (local), trenching and backfill, pipe material, bedding, installation and connection of piping, valves, fittings, traffic control, and paving. Each of these areas is discussed briefly below.

Saw cutting of existing pavement is necessary when the pipe installation is to be below a street or other paved surface. The operation consists of a single operator and a walk behind, self propelled, gas-powered saw. Values used in this calculation assume: 2 parallel cuts in 4 " thick asphalt over the trench.

Pavement removal occurs prior to trenching and after saw cutting. Depending upon the local conditions, it may be part of the trenching operation. This would be determined by the disposal used for the paving material. If disposal is possible at the same site as the trench spoils, costs for this operation may be reduced or eliminated. The assumption in the figures below is that the paving material must be disposed of separately from the trench spoil.

Hauling of pipe is generally required when working in urban areas. Piping material is stockpiled at a location other than the actual installation site. Hauling is necessary to move the pipe from the contractor's equipment yard to the installation site.

Trenching and backfilling are major cost components of the piping installation. The cost is heavily influenced by the prescence or abscence of other utilities in the pipeline corridor. Costs below are based upon trench widths of 36" wide for 3 or 4 " lines, $42^{\prime \prime}$ for 6 and 8 "lines, and 48" 
for 10 and 12" lines. Trench depth is 42 " for lines up to 8 ", and 60" for 10 and 12 inch lines. Soil is assumed to be stable (permitting 0:1 slope). Costs include trenching, backfilling, compaction and removal of spoil. A $50 \%$ penalty is added to account for working around existing utilities.

Pipe bedding is used to assure that the backfill material placed adjacent to the pipe is free of rocks and other objects which could cause damage to the casing or impede adequate compaction. Costs below assume the use of sand for bedding to a depth of 12" over the pipe. Compaction costs are included.

Installation includes lowering the pipe into the trench and connecting each length to the next. The pipe material is Tyton-joint ductile iron. Joining consists of inserting the rubber gasket, applying lubrication and drawing the two lengths of pipe together. Labor is based on values for installation of distribution water mains.

Valves are used in water distribution systems to isolate major branches so that service can be performed without shutting the entire system down. The costs below incorporate non-rising stem gate valves (with valve boxes) at 500-foot intervals. The actual valve spacing is dependent upon individual system design.

Fitting cost is influenced by the design of the system, existing utility and customer density. The costs below are reflective of moderate customer density and light existing utility interference. These costs assume two elbows and two tees per 200 feet of line.

Thrust blocks are required on unrestrained piping systems at all changes in direction, valves, tees and caps. They serve to resist the forces developed by the water pressure and flow direction changes. Thrust blocks are constructed by pouring concrete between the fitting and undisturbed soil. The size of the block is function of the pipe size, line pressure, and soil type. The costs below assume $2000 \mathrm{lb} / \mathrm{ft}^{2}$ soil and concrete costs of $\$ 200 \mathrm{yd}^{3}$. Blocks are assumed to be used for all the fittings cited above.

Traffic control is required around open trenches and similar construction in or near a roadway. The traffic control assumed in the costs below is based upon two flaggers working eight hours per day. The variation in cost is due to the lower installation output ( $\mathrm{ft} /$ day) for larger pipe sizes.

Paving is based on the placement of $4 "$ of asphalt concrete over the trenches at a cost of $\$ 32 / \mathrm{yd}^{2}$.

Table 1 provides a summary of the current base case costs for installation of preinsulated ductile iron piping. 
Table 1

Base Case Cost Summary - Ductile Iron Distribution Piping

Cut

\begin{tabular}{|c|c|c|c|c|c|}
\hline $3^{\prime \prime}$ & $4^{\prime \prime}$ & $6^{\prime \prime}$ & 8" & 0" & $12^{\prime}$ \\
\hline 4.12 & 4.12 & 4.12 & 4.12 & 4.12 & 4.1 \\
\hline 2.20 & 2.20 & 2 & & & \\
\hline 0.71 & 0.71 & 0.83 & 1.1 & 1.37 & .7 \\
\hline 8.83 & 8.83 & 10.01 & 10.01 & 16.31 & 16. \\
\hline 2.57 & 2.65 & 3.84 & 3.87 & 98 & 4.0 \\
\hline 8 & 30.75 & 34.23 & 45.48 & 57.63 & 64.4 \\
\hline 10.68 & 12.53 & 14.38 & 22.31 & 26.45 & 33. \\
\hline 3 & 3.00 & 4.17 & $6.0^{\prime}$ & .60 & 11.1 \\
\hline & 1.95 & 2.7 & 4.0 & 6.13 & \\
\hline & 0. & 1. & 2.8 & 4.44 & 6 \\
\hline & & & & & \\
\hline 10 & 106 & 12.48 & 2.48 & 14.08 & \\
\hline
\end{tabular}

Total

$\begin{array}{llllll}75.36 & 81.20 & 94.51 & 119.46 & 151.51 & 174.06\end{array}$

Figures 1,2, and 3 present this data in the form of percentages for 3,6, and 12 inch pipe sizes. It is apparent that the distribution of the costs is fairly stable over the range of pipe sizes. Costs for the pipe and installation constitute a somewhat higher percentage at the upper end of the size range; but, the difference is not significant (50.2\%@3", 56.9\%@12").

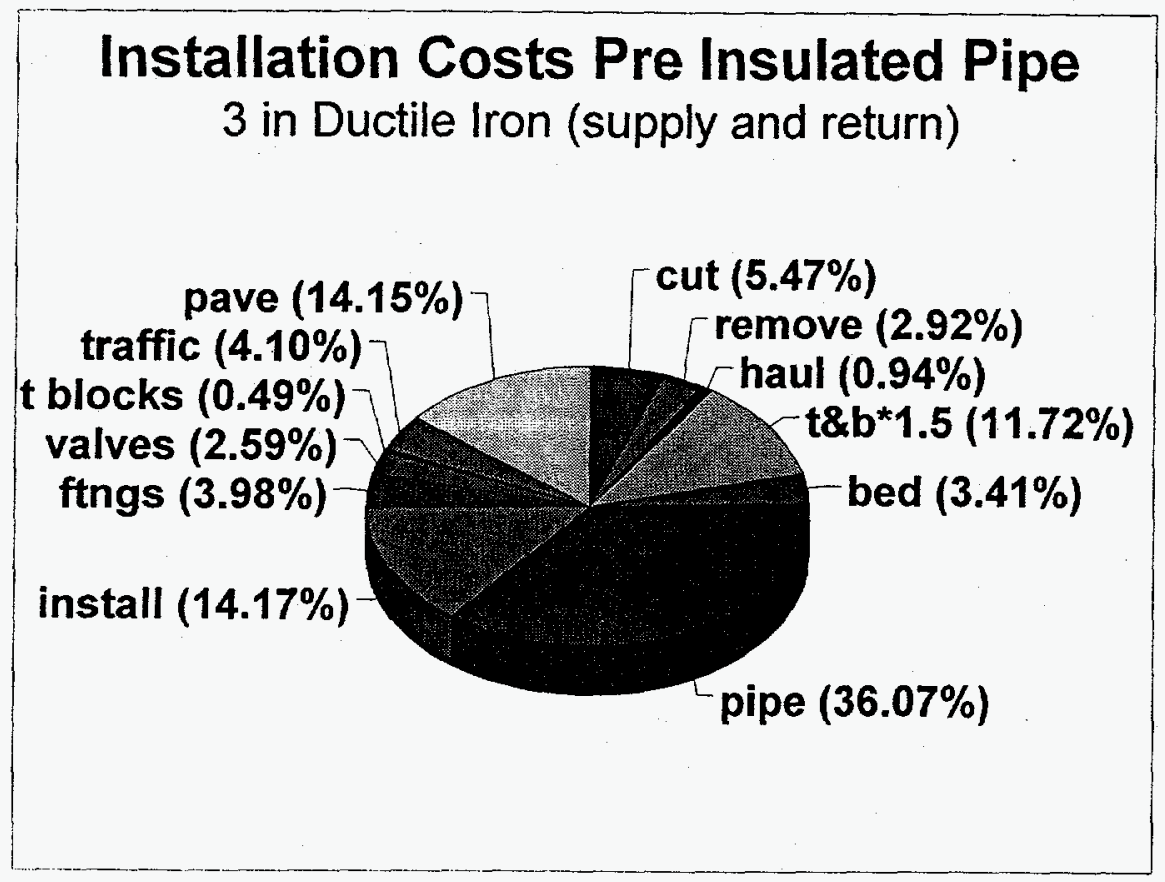

Figure 1. 


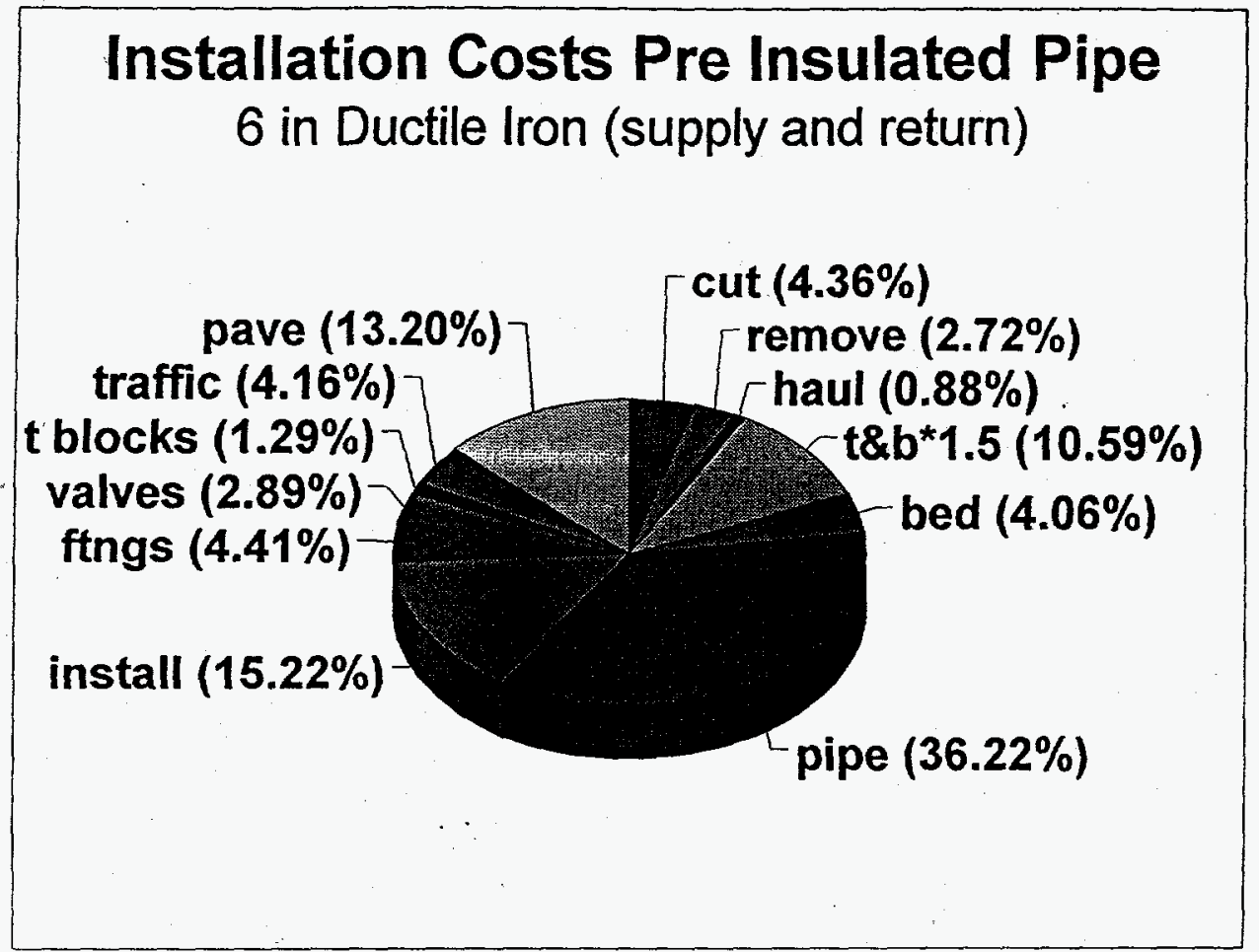

Figure 2.

\section{Installation Costs Pre Insulated Pipe}

12 in Ductile Iron (supply and return)

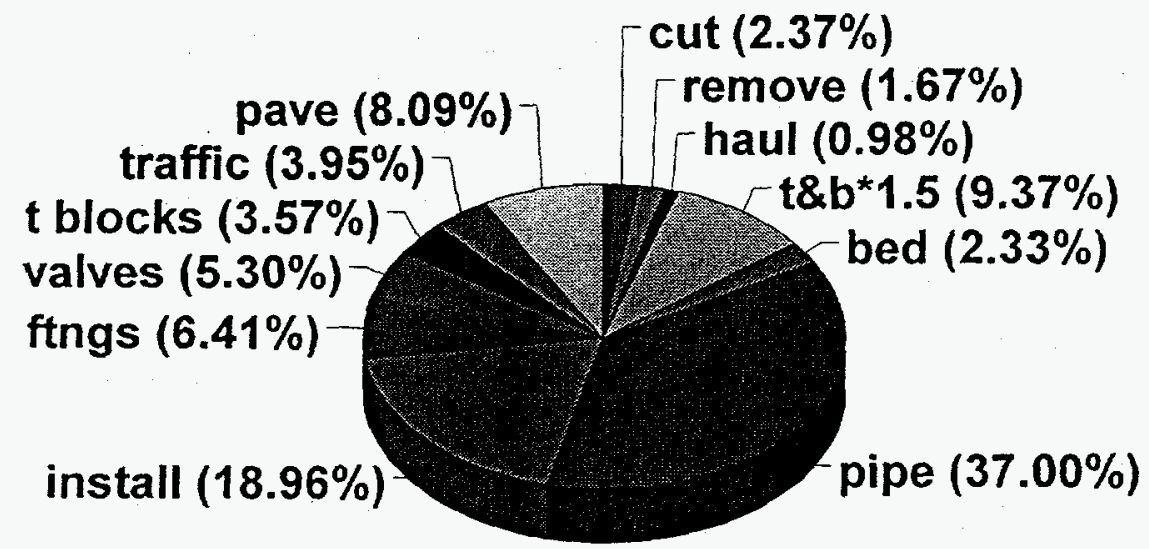

Figure 3. 


\section{Potential Cost Reduction}

Figure 4 presents a simplified representation of installation costs (6") using only five cost categories. The three largest cost categories, and hence, largest potential areas for cost reduction are: pipe and installation, trenching and backfilling, and pavement related costs.

It is clear that installation in unpaved areas holds the potential of substantial $(\sim 20 \%)$ cost reduction. In downtown business areas, the prospects for installation in unpaved areas is small. In residential areas, however, particularly areas developed prior to the $1960 \mathrm{~s}$, it is not uncommon to find unpaved alley ways between each block. Installation of distribution lines in these areas could, depending upon the line size, reduce per foot costs by $12 \%(12 ")$ to $22 \%$ (3"). In addition to these savings, it is possible that unpaved areas may not require the level of traffic control assumed for the downtown area in the basic cost calculations. If traffic control can be completely eliminated (such as closing the area during construction), a savings of approximately $4 \%$ could be realized.

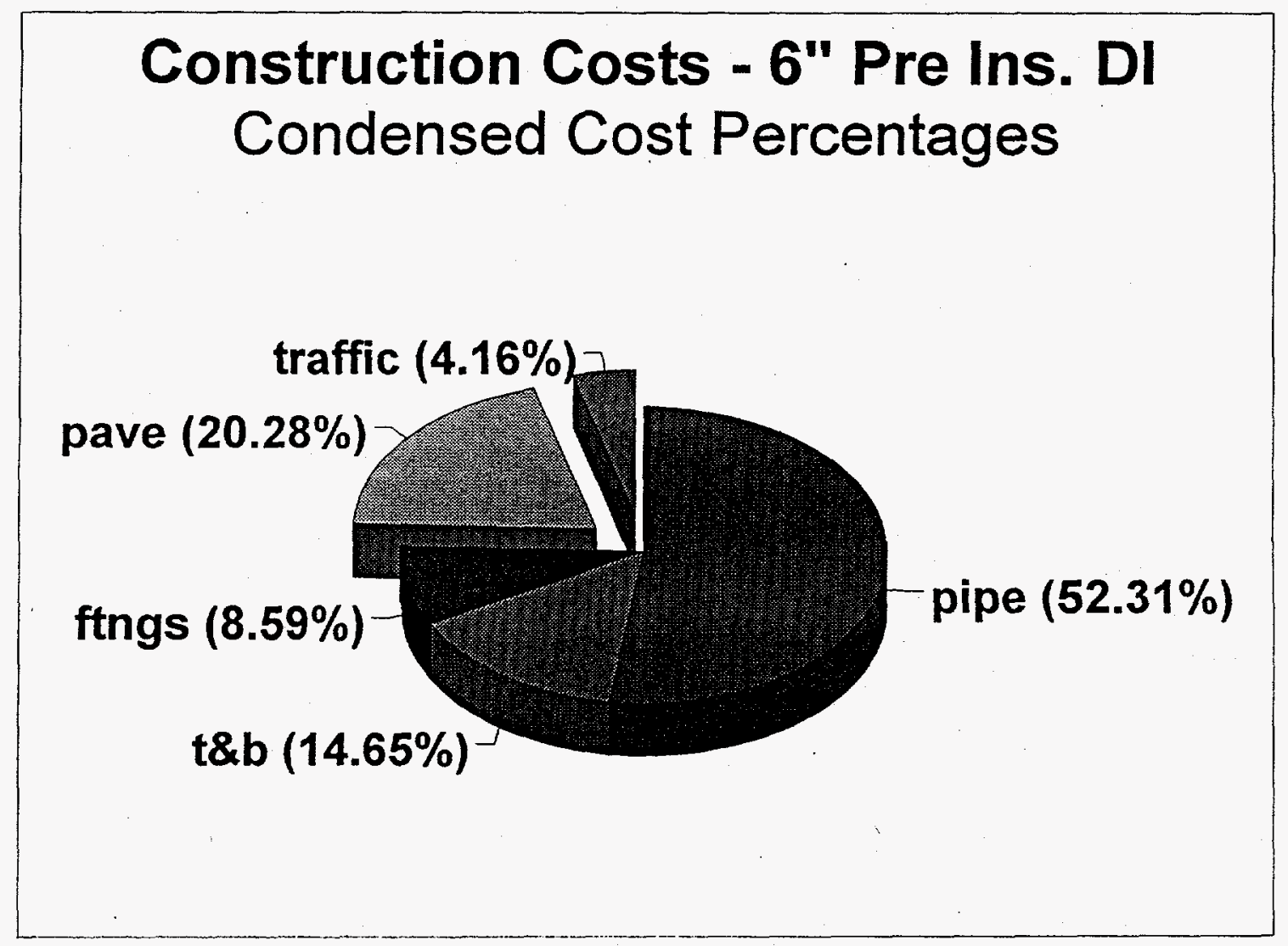

Figure 4. 
In the area of trenching and backfilling, there is a small opportunity for cost reduction if the pipeline corridor is free of existing utilities. The costs shown in Table 1 for trenching and backfilling, incorporate a $50 \%$ cost penalty for working around existing utilities. It is unlikely, even in residential areas to find a pipeline corridor completely free of obstruction; however, the potential exists for savings, in the $6^{\prime \prime}$ size, of up to $3.5 \%$ of per foot costs. The savings ranges from 3.9\%@3" pipe size to 3.1\% at the 12" size.

The largest portion of the installed cost is related to the piping itself. The costs for pipe material, hauling, and installation amount to approximately $50 \%$ of total costs over the range of piping size ( 3 " through 12") considered in this study. As a result, this area should offer the potential for savings.

Previous work (Rafferty, 1990; Rafferty, 1989) has identified preinsulated ductile iron as the lowest cost alternative to the previously used asbestos cement material. As a result, the opportunity to reduce costs through the use of an alternate preinsulated product is unlikely. In some cases, however, it may be possible to reduce costs by using uninsulated piping for distribution. A previous Geo-Heat Center publication (Rafferty, 1989) explored the practical feasibility of this approach and found it to be useful, particularly in larger pipe sizes $\left(>4^{\prime \prime}\right)$.

Due to corrosion considerations, any uninsulated piping would have to be of non-metallic construction. Uninsulated metallic piping operating at temperatures in the $120^{\circ} \mathrm{F}$ range can experience excessive exterior corrosion due to exposure to soil moisture. Efforts to deal with this problem using coatings have been unsuccessful (Rafferty, 1990).

Commercially available non-metallic materials suitable for the application include: fiberglass and CPVC piping. Some polybutylene was previously used in one district system; but, this material has very limited availability in the sizes considered in this report. Beyond that, it is unclear whether the material is supported by the manufacturers for continuous duty at temperatures in excess of $160^{\circ} \mathrm{F}$. Cross-linked polyethylene (PEX) is a product which is suitable for the temperature at pressures employed in district heating. It is a European product and its availability in this country is limited to preinsulated products in the 4 " and smaller nominal size range.

Fiberglass material of the epoxy resin type has been widely used in geothermal district heating sytems. The joining system which has been most successful is the adhesive bell and spigot (military specification) arrangement. Mechanical joining systems have encountered at least one major system wide failure and are not considered further here. Low cost fiberglass piping of the unlined type (commonly used in the oil industry) has also performed poorly in geothermal systems.

Table 2 presents cost data on uninsulated epoxy adhesive fiberglass piping compared to preinsulated ductile iron. 
Table 2

Savings - Uninsulated Fiberglass Return Line

\begin{tabular}{|c|c|c|c|c|c|c|}
\hline & FG Pipe & $\begin{array}{c}\text { Labor \& } \\
\text { Joining }\end{array}$ & & Preinsulated & & \\
\hline Size & Material & Materials & Total & DI & $\$ / \mathrm{ft}$ Savings & $\%$ Savings \\
\hline 3 & 9.21 & 2.39 & 11.60 & 18.93 & 7.33 & 9.7 \\
\hline 4 & 11.28 & 3.14 & 14.42 & 21.64 & 7.22 & 8.9 \\
\hline 6 & 16.56 & 5.00 & 21.56 & 24.30 & 2.74 & 2.9 \\
\hline 8 & 27.60 & 7.05 & 34.65 & 33.89 & -0.76 & -0.6 \\
\hline 10 & 40.98 & 9.89 & 50.87 & 42.04 & -8.83 & -5.8 \\
\hline 12 & 52.61 & 12.17 & 64.78 & 48.71 & -16.07 & -9.2 \\
\hline
\end{tabular}

Notes: Fiberglass piping as per vendor quote $+25 \%$ O\&P. Labor and material for joining epoxy adhesive type fiberglass, includes savings of $\$ 0.335 / \mathrm{ft}(3 ")$ and $\$ 0.035 / \mathrm{ft}$ (4") for elimination of thrust blocks and lower cost fiberglass fittings. Savings percentage indexed to base cost per foot (return line only) in Table 1.

The table assumes the use of only an uninsulated return line. It is also possible to use uninuslated supply; however, the savings of this approach are reduced due to the requirement for installation of temperature-maintenance control valves at strategic points on the system to assure adequate supply temperature to customers. When the control valve costs are deducted from the piping cost savings, the results are marginal to negative.

Table 3 presents some cost information for CPVC substitution. The costs for the uninsulated CPVC material actually exceeds the cost of the preinsulated DI. As a result, this material would not be a candidate for consideration.

Table 3

Savings - Uninsulated CPVC Return Lines

$\begin{array}{cc}\frac{\text { Size }}{3} & \text { CPVC Pipe and Labor } \\ 4 & 21.01 \\ 6 & 26.04 \\ & 44.49\end{array}$

\begin{tabular}{c} 
Preinsulated DI \\
\hline 18.93 \\
21.64 \\
24.30
\end{tabular}

\begin{tabular}{c} 
Savings $\$ / \mathrm{ft}$ \\
\hline-2.08 \\
-4.40 \\
-20.19
\end{tabular}

Note: CPVC costs include credit for eliminated thrust blocks, adjustment for fitting costs $\left(-0.195\left(3^{\prime \prime}\right),+0.15\left(4^{\prime \prime}\right),+1.31\left(6^{\prime \prime}\right) \$ / f t\right)$. CPVC figures from Means Mechanical Cost Data, 1996.

Table 4 presents a summary of distribution system costs on a per foot basis for sizes 3 " through 12 " assuming the optimistic case where all of the potential cost reductions identified in this section could be implemented. These would include: unpaved area for installation, no existing utilities in the pipe line corridor, uninsulated return lines ( 3 " and 4 " sizes), and no active traffic control requirement. 
Table 4

Distribution Construction Costs - Incorporates All Reductions

Cut

Remove

Haul

Trench and Backfill

Bed

Pipe

Installation

Fittings

Valves

Thrust Blocks

Traffic

Pave

Total
Line Sizes

$\frac{3^{\prime \prime}}{0} \frac{4^{\prime \prime}}{0} \frac{6^{\prime \prime}}{0} \frac{8^{\prime \prime}}{0} \frac{10^{\prime \prime}}{0} \frac{12^{\prime \prime}}{0}$

0

0.71

0

0

0.83

0

5.89

0.71

6.67

$\begin{array}{ll}1.14 & 1.37\end{array}$

$\begin{array}{ll}6.67 & 10.87\end{array}$

1.71

$2.57 \quad 2.65$

3.84

22.80

26.65

34.23

9.06

10.44

14.38

2.60

3.15

1.95

1.95

4.17

2.73

0.19

1.22

0

$\frac{0}{\$ 45.85} \frac{0}{\$ 51.63}$

0

\begin{tabular}{ll}
6.87 & 3.98 \\
\hline
\end{tabular}

$45.48 \quad 57.63$

$22.31 \quad 26.45$

\begin{tabular}{l}
$6.02 \quad 8.60$ \\
\hline .07
\end{tabular}

4.07

6.13

4.44

2.81

0

0

$\frac{0}{\$ 68.07}$

$\frac{0}{\$ 92.37} \frac{0}{\$ 119.47} \frac{0}{\$ 140.67}$

Base Case

$75.36 \quad 81.20$

94.51

119.46

151.51

174.06

$29.51 \quad 29.57$

26.44

27.09

32.04

33.39

$\%$ Savings/ft

27.9

$22.7 \quad 21.1$

19.2

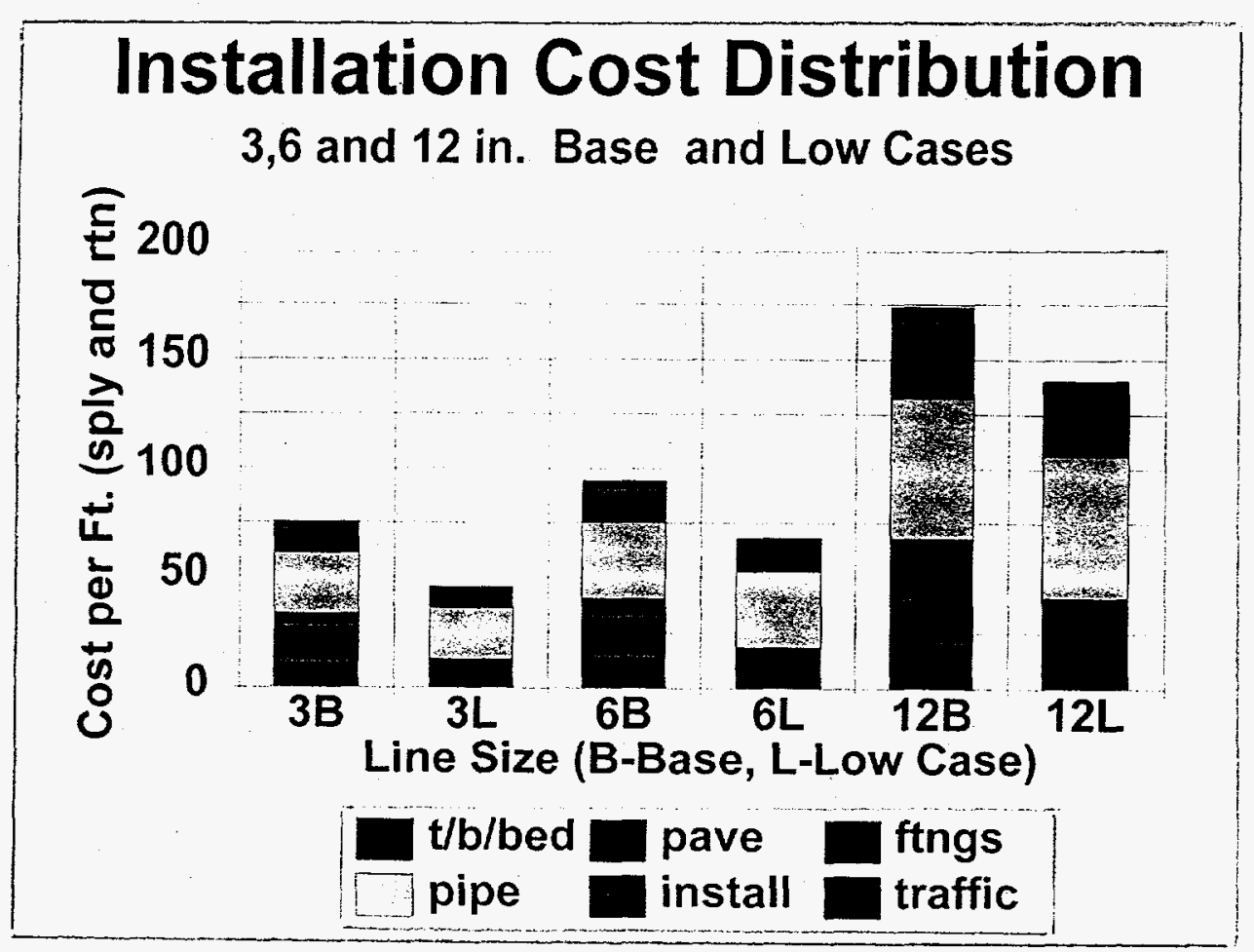

Figure 5. 
Figure 5 presents this information graphically for 3", 6" and 12" lines sizes. This figure combines the individual cost areas into six basic groups. It is apparent that the largest savings potential occurs in the smallest piping sizes (3" and 4"), This occurance benefits the residential distribution case since a majority of the distribution systems piping would be in the smaller pipe sizes.

\section{INDIVIDUAL VS. CENTRAL HEAT EXCHANGER}

It is advisable in all geothermal direct use systems to isolate the geothermal fluid from the building heating system it serves. This strategy greatly reduces the extent of geothermal fluid chemistry induced corrosion and scaling in the user's system. In district heating systems, there are two approaches to this isolation:

- Indirect system - central heat exchanger facility with a treated water loop serving the customer, and

- Direct system - geothermal fluid is delivered directly to the customer and an individual heat exchanger (or exchangers) is located at each user.

Due to the economics of scale in large heat exchangers and pumps, it is reasonable to assume that there will be a point when the cost of a large number of individual heat exchangers will exceed that of larger central equipment. This cross-over point is influenced by the loads served along with water temperature.

There are typically two loads to be served at the residential level: space heating and domestic hot water. In some areas, pools, hot tubs and possibly driveway snow melting may be present. These loads, however, are not present in every customer and tend only to be present in higher income, large lot developments in which load density would be inadequate for practical consideration of district heating. As a result, space and domestic hot water loads are the principal targets in small- and moderate-sized western U.S. towns where geothermal systems would be likely located.

Many approaches are possible to address serving these two loads and the specific choice is influenced by, among other things, available supply water temperature from the district system. It is useful, if possible, to place the two loads in series in order to maximize temperature drop and minimize flow requirements.

Domestic hot water heating generally involves a heat exchanger, circulating pump, storage tank and controls as the major components. Figure 6 presents a common arrangement. The domestic hot water is isolated from the district water with a heat exchanger. Domesitc cold water, depending upon the flow, enters the sytem through the heat exchanger or partially through the heat exchanger, and partially through the storage tank. The circulating pump responds to the thermostat on the tank to provide reheat of storage as necessary. The pump and the control valve on the heating water are interlocked to operate together. The domestic hot water circuit may be placed in series with (either up or down stream depending upon the application) the space heating load. 


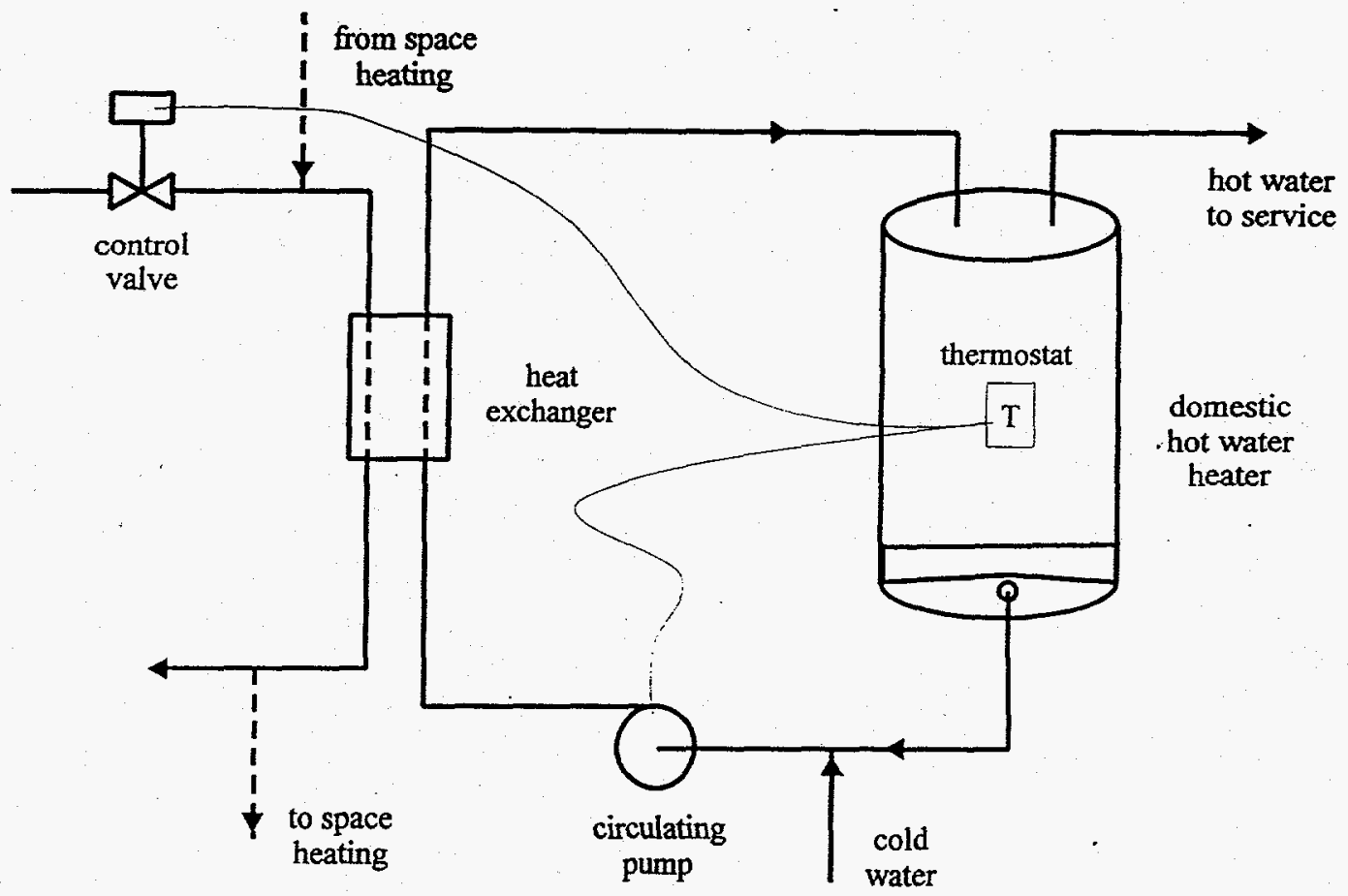

Figure 6.

Space heating in residences is rarely accomplished with hot water heating in the western states. Most homes use some form of forced-air system (heat pump, propane, gas or electric furnace or electric baseboards units). As a result, in order to heat the residence with a hot water source, a system similar to Figure 7 is required.

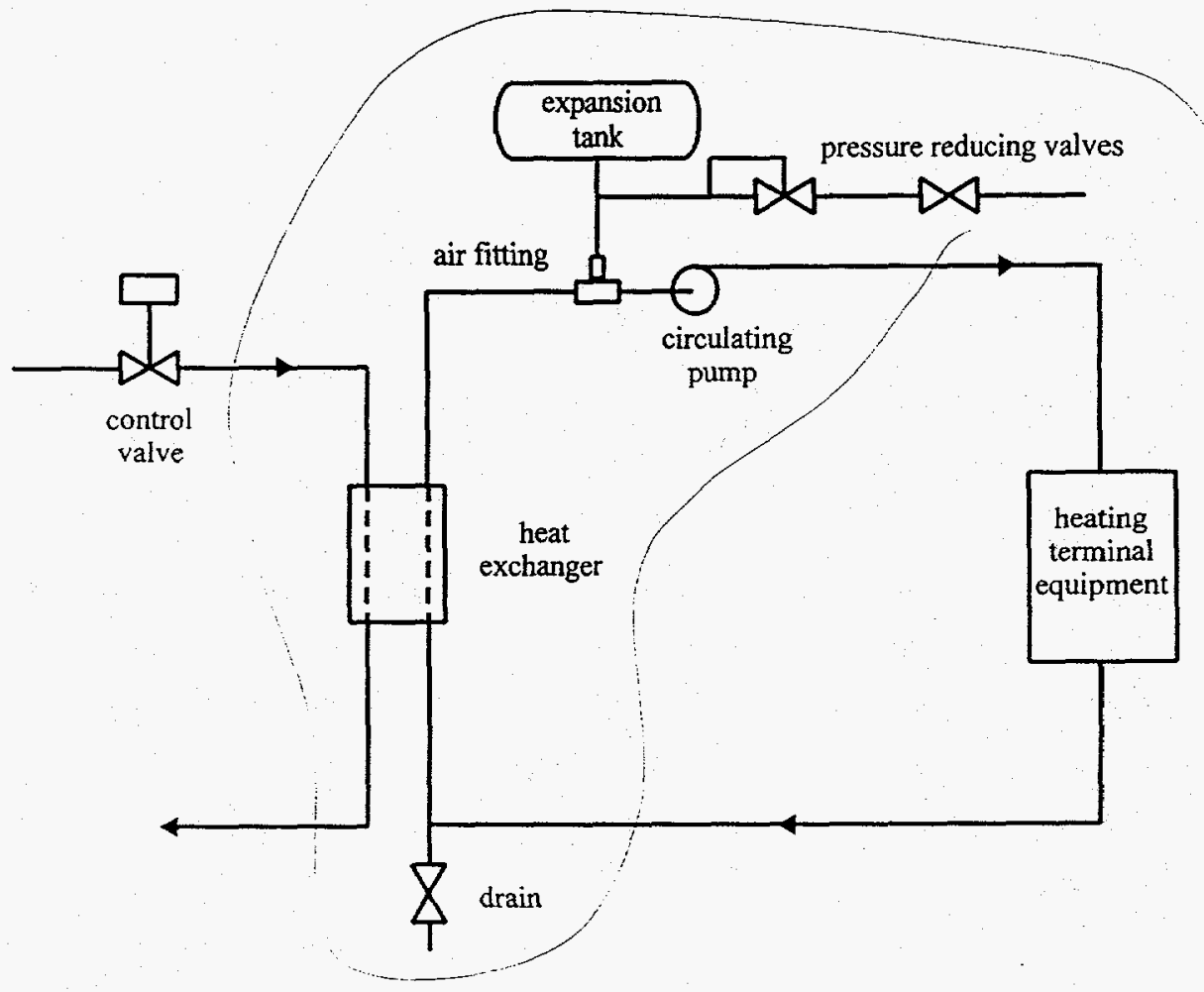

Figure 7. 
Heat is transferred from the district system fluid, through the heat exchanger to the building loop. On the building side, a circulating pump provides flow to the terminal unit (or units) after which it is returned to the heat exchanger for reheating. To maintain pressurization, an expansion tank and domestic water pressure reducing valve are included on the loop. A room thermostat controls the circulating pump and heating water control valve on a call for heat.

The space heating equipment required can be reduced substantially if an indirect district system is employed. In this approach, the heat exchanger, expansion tank, pressure reducing valve, city water cross connection and circulating pump along with their associated fittings can be eliminated. For a typical home with a heating system designed for a load of 75,000, Table 5 summarizes the costs of the components which could be eliminated in an indirect system.

Table 5

Residential Heat System Components Eliminated with Indirect District System Design

Item

Brazed-plate heat exchanger

Circulating pump 4 gpm @ 25' 1/20 hp

Pump electrical

Drain (1/2" boiler)

2 Valves, 1" gate

Expansion tank, 2 gal.

Air fitting 1"

Pressure reducing valve $1 / 2^{\prime \prime}$

Gate valve $1 / 2^{\prime \prime}$

Water line $25^{\prime} 1 / 2^{\prime \prime}$ copper
Cost

$\$ 265$

282

40

30

60

87

55

84

30

114

Subtotal $\$ 1,047$

Contingency $\quad \underline{209}$

Total $\$ 1,256$

In order to eliminate these items, a central heat exchanger plant would be required to provide the same function (isolation of the building system from the geothermal fluid). The central plant would contain the same type of equipment (circulating pumps, heat exchangers, expansion tanks, controls and pressurization equipment), but on a larger, more economical scale. Table 6 presents a summary of the cost associated with central plants of 5,000,000;10,000,000 and 20,000,000 Btu/hr capacity. 
Table 6

Central Plant Costs - Indirect System

Heat exchangers (2)

Instrumentation \&

Controls

Piping

Pumps (2)

Building

Subtotal

$20 \%$ Contingency

Total
$5,000,000 \mathrm{Btu} / \mathrm{hr}$

$\$ 11,000$

$$
8,000
$$

6,700

3,800

24,000

53,100

10,600

$\$ 63,700$
$10,000,000 \mathrm{Btw} / \mathrm{hr}$

$\$ 22,000$

8,100

8,700

6,300

$\underline{32.000}$

77,100

15,400

$\$ 82,500$ $\underline{20,000,000 \mathrm{Btu} / \mathrm{hr}}$

$\$ 33,500$

8,300

15,500

6,800

32.000

96,100

19,300

$\$ 115,300$

The figures in Table 6 assume the use of two 100\% heat exchangers and two 100\% circulating pumps along with the necessary controls and piping housed in a steel building.

Figure 8 compares the cost of the individual customer heat exchanger to the cost of the central plant. The plot is based on the assumption of a $75,000 \mathrm{Btu} / \mathrm{hr}$ load at each customer. It is apparent that a lower cost results for the use of a central plant under all conditions of 5,000,000 $\mathrm{Btu} / \mathrm{hr}$ system capacity and above. This would correspond to a customer count of approximately 66 homes. Extrapolating these curves slightly suggests that the break-even point would occur at approximately $3,000,000 \mathrm{Btu} / \mathrm{hr}$ system capacity or about 40 homes at $75,000 \mathrm{Btu} / \mathrm{hr}$ each.

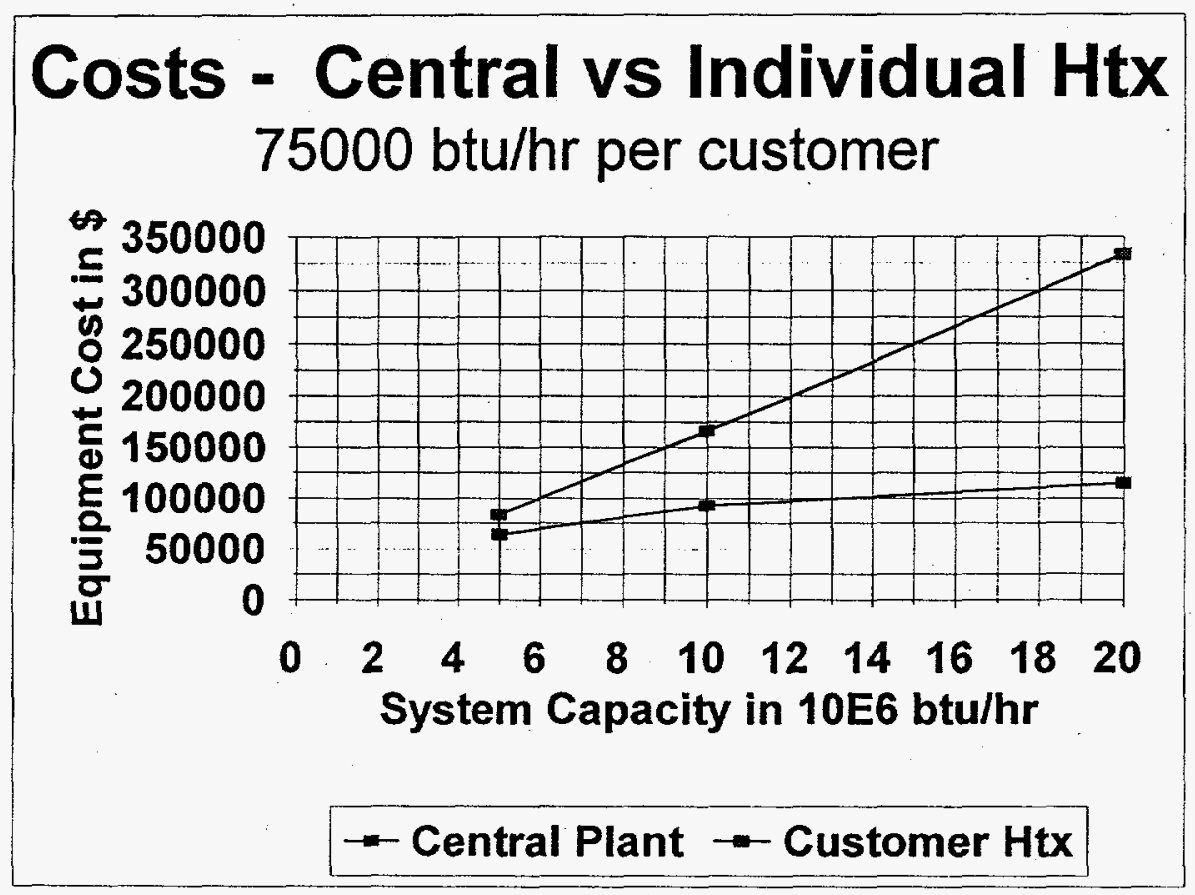

Figure 8. 


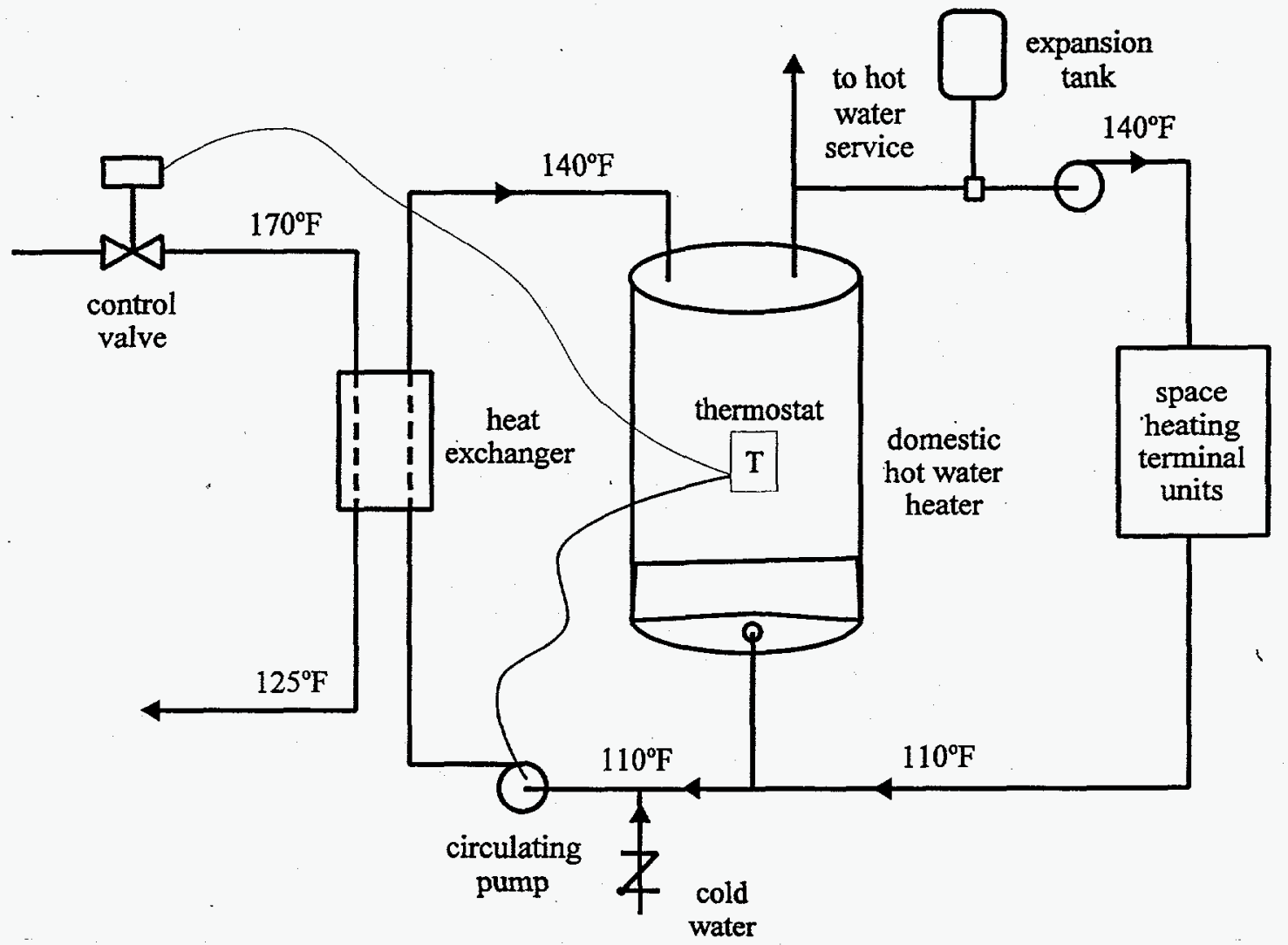

Figure 9.

There is a possible exception to the central plant vs. customer heat exchanger discussion above. For systems which distribute higher temperature (above about $150^{\circ} \mathrm{F}$ ) water, the domestic hot water and space heating system can be combined. Figure 9 presents a simplified flow scheme for this arrangement. Under this approach, a single heat exchanger provides the heat for both the space heating and domestic hot water. The storage tank provides both potable hot water and a reservoir from which the space heating supply water is drawn. In order to accommodate this arrangement, the space heating loop must be plumbed to potable water standards (copper piping, bronze fitted pump, lead-free solder, etc.) and a somewhat larger storage tank is generally used. A space heating circulating pump and expansion tank are also required. As a result, the savings to be achieved through the use of an indirect distribution system are less for this design than for the two heat exchanger designs described above. To date, no geothermal district heating system in the U.S. has employed a combined space and domestic hot water heating system. In the nondistrict heating arena, the natural gas industry is promoting a gas-fired version of this design. If a combined space and domestic hot water customer design is possible (regulatory approval and available supply water temperatures $>150^{\circ} \mathrm{F}$ ), an open-type distribution system would result in lower system development costs.

\section{CUSTOMER BRANCH LINES}

One of the major cost items for small customers of a district heating system is branch lines. These lines connect the customer building with a curb valve box (and ultimately the distribution lines in the street). 
In a single-family setting, these lines are likely to be a minimum of 60 feet in length $\left(5,000 \mathrm{ft}^{2}\right.$ lot with the home placed in center of lot) and due to their size (typically $3 / 4^{\prime \prime}$ to $11 / 2$ ": nominal diameter) varying flow and potential damage to overlying vegetation, insulation is unavoidable.

Assuming a central plant design for the distribution system (treated water to customers), there are three realistic choices for the piping material: preinsulated copper, field insulated copper and preinsulated flexible polyethylene (cross-linked polyethylene or "PEX").

The attractiveness of the preinsulated products lies in the elimination of the field labor otherwise necessary to install the insulation. The flexible material offers an added attractiveness of reduced fitting labor if it is necessary to route the branch piping around obstacles.

Table 7 provides a summary of the costs for the three materials.

Table 7

Cost Summary Branch Lines - 1"

\begin{tabular}{|c|c|c|c|}
\hline & $\begin{array}{l}\text { Field Insulated } \\
\text { Copper (Type K) }\end{array}$ & $\begin{array}{l}\text { Preinsulated } \\
\text { (Type K) }\end{array}$ & $\begin{array}{l}\text { Preinsulated } \\
\text { Flexible PEX }\end{array}$ \\
\hline Trench & 1.30 & 1.30 & 1.30 \\
\hline Backfill & 2.32 & 2.32 & 2.32 \\
\hline Material (pipe) & 5.37 & 16.04 & 16.85 \\
\hline Insulation (incl. labor) & 1.38 & -- & -- \\
\hline Fittings & -- & -- & 3.45 \\
\hline Installation & 9.04 & 3.35 & 2.04 \\
\hline Subtotal & 19.41 & 23.01 & 25.96 \\
\hline $20 \%$ contingency & 3.88 & 4.60 & 5.19 \\
\hline Total & 23.29 & 27.61 & 31.15 \\
\hline
\end{tabular}

It is apparent that the field insulated copper enjoys a cost advantage over the remaining materials, particularly preinsulated PEX. The above costs were calculated assuming the use of prevailing wage (union) rates). If non-union labor is employed, the cost difference between the field insulated material and the other products would increase due to its larger labor component.

The flexible piping material only price is attractive when compared to the preinsulated copper. It's associated fittings, however, tend to erode it's competitiveness. Because the carrier pipe is polyethylene, special fittings are required to transition to standard copper or steel. In addition, end caps are required to protect the insulation. When the cost of these items is included, the overall cost exceeds that of the preinsulated copper.

Based on the use of the field-insulated copper branch piping, and a distance of $60 \mathrm{ft}$ from the curb box to the house wall, a figure of approximately $\$ 1400$ per house results. 


\section{DISTRIBUTION COST VS. REVENUE POTENTIAL}

Heat load density has been a primary index by which district heating feasibility has been measured in the past. This value is calculated by dividing the total heat energy consumed by some convenient area unit (acre, $\mathrm{ft}^{2}$, etc.). The magnitude of the heat load density (Btu/acre for example) is then used to determine the feasibility of district heating service in a particular area. Specific heat load density values have been developed in the past which are considered to be attractive for system development. In many areas, however, this value may not be appropriate for use in evaluating geothermal district heating due to its unique economics. This is particularly true with regard to the unique application of existing single-family residential areas.

The theory of heat load density as a basis for district heating feasibility is a valid one in so far as it can be used to directly translate into potential district revenue. Revenue potential is evaluated by simply multiplying the load density by the cost of the conventional fuel which would otherwise be used to meet the load along with an adjustment for the expected customer penetration rate. In Europe where the practice was developed and to a large extent in downtown city systems here in the U.S., this is a relatively straightforward process. The heating system and conventional fuels used by potential customers are fairly uniform.

In residential areas, there can be wide variations in the type of heating system used. This results in similar variations in the cost of conventional heat. From electric and propane heat on the high cost end, to wood and natural gas at the low end, there may be a variation in heating cost of 4 or 5:1. As a result, it is critical in residential evaluations to consider both the heat load density and the cost of competing heating methods to arrive at potential revenue for a given area.

In order to evaluate the overall economics of district heating in moderate density residential areas, a specific section of Klamath Falls, known as the Mills Addition, provides a convenient example. This area is characterized by relatively small lot sizes $\left(-5000 \mathrm{ft}^{2}\right)$ and includes unpaved alleyways between each block which could potentially be used for piping installation. This area is representative of similar single-family residential subdivisions in small-to-moderate sized western U.S. cities. Figure 10 shows a section of this area. A distribution system layout appears in Figure 11. This layout would accommodate 256 homes. 


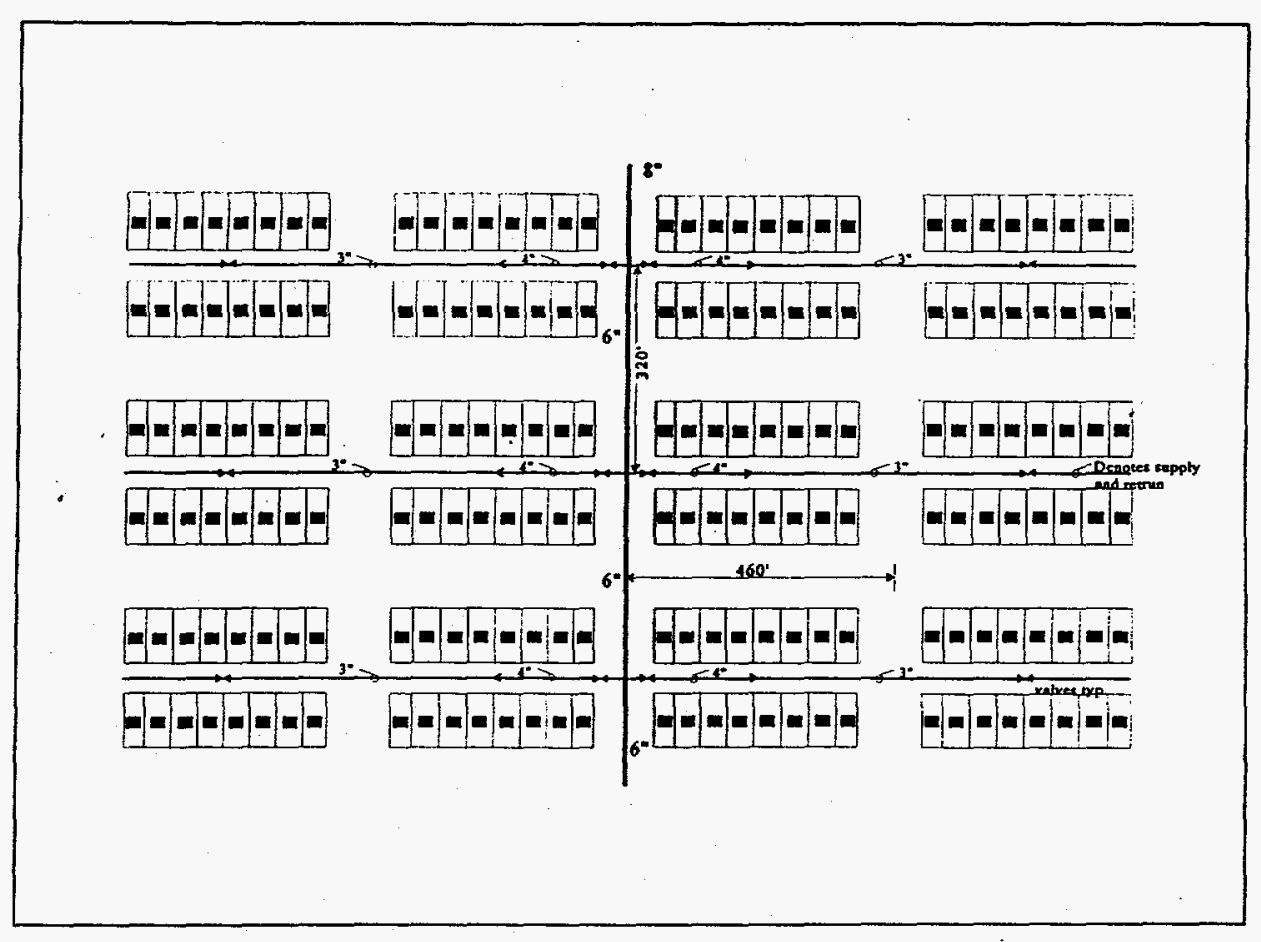

Figure 10.

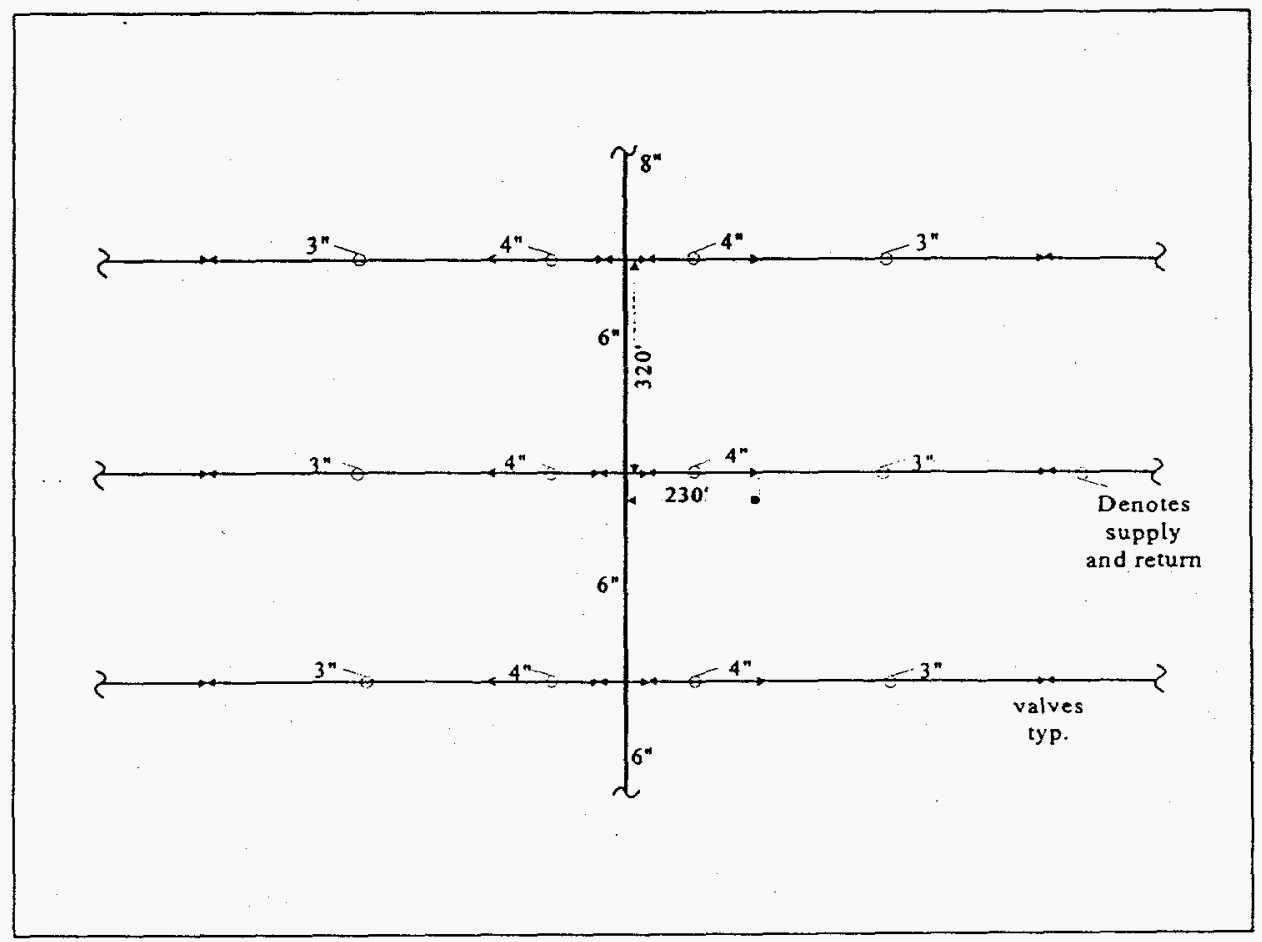

Figure 11. 
Table 8 presents a cost breakdown for the distribution system. This table assumes installation under the existing paved streets and uses the base-case cost values from Table 1. Table 9 presents a similar cost calculation using

Table 8

Base Case Capital Cost - Mills Addition Distribution

\begin{tabular}{lrrr}
$\underline{\text { Size }}$ & $\underline{\text { Length }}$ & $\underline{\text { Unit Cost }}$ & Total \\
\hline $3^{\prime \prime}$ & $5,520^{\prime}$ & $\$ 75.36$ & $\$ 415,987$ \\
$4^{\prime \prime}$ & $1,840^{\prime}$ & 81.20 & 149,408 \\
$6^{\prime \prime}$ & $960^{\prime}$ & 94.51 & 90,730 \\
$8^{\prime \prime}$ & $160^{\prime}$ & 119.46 & $\underline{19,114}$ \\
& \multicolumn{3}{c}{ Branch lines (street to } \\
\multicolumn{3}{c}{ curb box) } & 128,000 \\
& \multicolumn{2}{c}{ Total } & $\$ 803,239$
\end{tabular}

Table 9

Low Case Distribution Capital Cost - Mills Addition

\begin{tabular}{|c|c|c|c|}
\hline$\underline{\text { Size }}$ & Length & Unit Cost $t^{(1)}$ & Totals \\
\hline 3" & $5,520^{\prime}$ & $\$ 45.85$ & $\$ 253,092$ \\
\hline 4" & $1,840^{\prime}$ & 51.63 & 94,999 \\
\hline 6" & 960 & 67.46 & 64,762 \\
\hline \multirow[t]{3}{*}{$8 "$} & 160 & 90.96 & 14,554 \\
\hline & & $\begin{array}{l}\text { Branch lines (street to } \\
\text { curb box) }\end{array}$ & 128,000 \\
\hline & & Total & $\$ 555,407$ \\
\hline
\end{tabular}

(1) Assumes unpaved area, no existing utilities, uninsulated return line (3" and 4 "only), no traffic control requirements.

Using the above values to bracket the distribution system costs, and adding central plant and resource development costs permits a calculation of the total system cost for this residential area.

The example area contains 256 homes which average $1100 \mathrm{ft}^{2}$ in size. Using a value of $40 \mathrm{Btu} / \mathrm{hr}$ per $\mathrm{ft}^{2}$ (uninsulated walls, single glass, R-19 attic insulation, 1 air change per hour (ACH) and allowing $30,000 \mathrm{Btu} / \mathrm{hr}$ for domestic hot water heating, results in a value of $74,000 \mathrm{Btu} / \mathrm{hr}$ per home. Using a $70 \%$ load diversity factor, the required plant capacity for 256 homes would amount to $13.3 \times 10^{6} \mathrm{Btu} / \mathrm{hr}$. From Figure 8, the plant cost for this capacity would be approximately $\$ 225,000$. 
Resource development costs can vary widely. To evaluate these costs a spreadsheet previously developed by the Geo-Heat Center (Rafferty, 1995) can be used to evaluate several alternatives. Average values for currently operating district heating systems can be characterized as follows.

Table 10

Average Geothermal Resource Values - Existing GDH Systems

$\begin{array}{ll}\text { Well depth } & 1500^{\prime} \\ \text { Water temperature } & 170^{\circ} \mathrm{F} \\ \Delta \mathrm{T} & 40^{\circ} \mathrm{F} \\ \text { Injection } & \text { No } \\ \text { Pumping required } & \text { Yes } \\ \text { No. production wells } & 2 \\ \text { No. injection wells } & 1 \\ \text { Static water level } & 200\end{array}$

Using the above mentioned spreadsheet, a capital cost for a system meeting the above parameters amounts to $\$ 406,000$. Table 11 presents some alternative cases based on realistic variations in the parameters shown in Table 10.

Table 11

Variations in Geothermal Resource Development Costs

$\begin{array}{lrrrrrrr}\text { Well depth (ft) } & 1500 & 1000 & 1000 & 2000 & 2000 & 500 & 500 \\ \text { Water temperature }\left({ }^{\circ} \mathrm{F}\right) & 170 & 170 & 170 & 170 & 170 & 170 & 170 \\ \Delta \mathrm{T}\left({ }^{\circ} \mathrm{F}\right) & 40 & 50 & 40 & 50 & 40 & 50 & 40 \\ \text { Injection } & \mathrm{Y} & \mathrm{N} & \mathrm{Y} & \mathrm{N} & \mathrm{Y} & \mathrm{N} & \mathrm{Y} \\ \text { Pumping required } & \mathrm{Y} & \mathrm{Y} & \mathrm{Y} & \mathrm{Y} & \mathrm{Y} & \mathrm{Y} & \mathrm{Y} \\ \text { No. production wells } & 2 & 1 & 1 & 1 & 2 & 1 & 2 \\ \text { No. injection wells } & 1 & 0 & 1 & 0 & 1 & 0 & 1 \\ \text { Static level (ft) } & 200 & 200 & 200 & 300 & 300 & 100 & 100 \\ \text { Cost }(\$) & \$ 406,000 & 230,000 & 390,000 & 330,000 & 540,000 & 140,000 & 310,000\end{array}$

It is apparent that there is wide variation in the potential cost of resource development. These variations are influenced primarily by well depth requirements, number of production wells and whether or not injection is employed. The range of values in Table 11 covers over $80 \%$ of all currently operating geothermal district heating systems. 
Table 12 summarizes the range of costs for the three major portions of the district system. The low case assumes minimum resource development costs and distribution system installation costs. The high case incorporates the maximum value (used in this report) for resource development and distribution.

Table 12

Expected Cost Range for 256 Homes GDH System

\begin{tabular}{|c|c|c|}
\hline & Low & High \\
\hline Resource & $\$ 140,000$ & $\$ 540,000$ \\
\hline Central plant & 225,000 & 225,000 \\
\hline Distribution & $\underline{555,000}$ & 803,000 \\
\hline & $\$ 920,000$ & $\$ 1.568 .000$ \\
\hline
\end{tabular}

Given the range in potential capital costs to implement the system, it is possible to calculate the required revenue to support the financing of this cost. At prevailing interest rates $(8 \%)$, the revenue required to cover the debt service only would amount to between $\$ 86,800$ and $\$ 148,000$. Assuming $75 \%$ subscribership, the necessary revenue per home would amount to a range of $\$ 452$ to $\$ 771$ (the low and high cases respectively).

In order to evaluate the feasibility of district heating, it is necessary to determine the current conventional heating costs in the service area. Previous work by the Geo-Heat Center (Rafferty, 1992) has identified an energy consumption for all gas homes in this area of approximately 0.80 therms per square foot for space and domestic hot water heating. Table 13 presents the current cost data for meeting the same loads based on the use of different fuels and fuel combinations.

Based on the required revenues for debt service resulting from the capital costs for system development, it appears that the best prospects would be in areas other than those served by natural gas. Although the required revenue is (at the low end) less than all conventional heating costs with the exception of the $50 \%$ wood $/ 50 \%$ gas case, the margin left to cover system operating costs and homeowner savings for the natural gas cases, would not be sufficient to result in a feasible scenario.

The fuel oil, propane and electric heating cases, even with $50 \%$ wood substitution, result in conventional heating costs in the $\$ 700$ to $\$ 1000$ per year range. This range, assuming low- to moderate-system development costs would be sufficient to cover debt service requirements. The costs for remaining system development and operating costs along with customer retrofit costs would determine overall feasibility. 
Table 13

Annual Conventional Heating Costs

\begin{tabular}{lr} 
Fuel & $\$ / y r$ \\
\hline All gas & 484 \\
Gas with electric hot water & 638 \\
$50 \%$ gas $/ 50 \%$ wood/gas hot water & 439 \\
Fuel oil with electric hot water & 716 \\
$50 \%$ fuel oil $/ 50 \%$ wood/electric hot water & 632 \\
All propane & 977 \\
$50 \%$ propane/50 wood/electric hot water & 763 \\
All electric & 1,053 \\
$50 \%$ electric/50\% wood/electric hot water & 801
\end{tabular}

Notes:

Fuel oil @ \$0.95/gal

Natural gas @ \$0.55/therm

Propane@ @1.00/gal

Electricity@\$0.06/kWh

DHW@ $55^{\circ} / 130^{\circ}, 65 \%$ efficiency (fuels), 48 therms

$(840 \mathrm{kWh})$ standby tank loss

Fossil fuels @ 70\% efficiency, wood @ 50\% efficiency

\section{CONCLUSIONS}

Based on the example residential area used in this report, some general conclusions can be drawn with regard to a number of areas influencing the economics of district heating in existing singlefamily residential areas.

Distribution system piping for many recent additions to geothermal district heating systems has been of preinsulated ductile iron (DI). Use of this material is driven by its low cost, ease of installation and proven track record. Current costs for installation of DI (supply and return) in developed areas amounts to approximately $\$ 95.00$ per foot in the 6 inch size (range $\$ 75.00 @$ 3." to $\$ 174.00 @ 12 ")$. Installation of distribution piping in residential areas offers several opportunities for reducing these costs. Placing the pipeline under unpaved areas can reduce costs $12 \%(12$ ) to $22 \%$ (3") by eliminating costs associated with saw cutting removing and repaving the area. The use of uninsulated return piping offers the prospect for modest savings in the smaller pipe size range. Assuming the use of uninsulated fiberglass (epoxy adhesive joining) to replace the return lines, a savings of $9.3 \%$ in $3 ", 8.9 \%$ in $4^{\prime \prime}$ and $2.5 \%$ in $6^{\prime \prime}$ sizes can be made. In larger pipe sizes, the cost of the bare fiberglass material exceeds that of the preinsulated DI.

If no existing buried utilities are located along the pipeline route, a savings of $3 \%$ to $4 \%$ (depending upon line size) can be achieved through reduced trenching costs. 
Traffic control during construction is almost always necessary in downtown areas. It is possible that some or all active traffic control could be eliminated in residential areas by simply closing the area under construction. Eliminating the labor for active traffic control offers a savings of approximately $4 \%$ over the range of line sizes $(3 "-12 ")$ covered in this report.

Using all of the above potential reductions results in the savings summarized in Table 14

Table 14

Summary of Potential Cost Reduction - Distribution Piping

\begin{tabular}{cccc} 
Size & $\begin{array}{c}\text { Base } \\
\text { Cost }(\$ / 1 \mathrm{f})\end{array}$ & $\begin{array}{c}\text { Lowest } \\
\text { Cost }(\$ / 1 \mathrm{f})\end{array}$ & $\begin{array}{c}\% \\
\text { Reduction }\end{array}$ \\
\hline $3^{\prime \prime}$ & 75.36 & 45.85 & 39.2 \\
$4^{\prime \prime}$ & 81.20 & 51.63 & 36.4 \\
$8^{\prime \prime}$ & 94.51 & 68.07 & 28.0 \\
$10^{\prime \prime}$ & 119.46 & 92.37 & 22.7 \\
$12^{\prime \prime}$ & 151.51 & 119.47 & 21.1 \\
& 174.06 & 140.65 & 19.2
\end{tabular}

Note: Assumes installation in unpaved area, no existing utilities, no active traffic control, uninsulated return (in sizes 3", 4", and 6").

Because much of the distribution system in residential areas is in the small size range ( 3 " and $4 "$ ), the potential cost savings relative to a downtown area is significant. To evaluate this, a distribution system was laid out for an existing area of Klamath Falls, known as the Mills Addition. The system was designed to serve 256 homes and consisted of line sizes in the $3 "-8$ " range. Also included was costs for branch lines to the curb for each customer. Using the lowest cost values from Table 14, the total distribution system cost for this example area was reduced $31 \%$ relative to the base case.

For systems serving more than about 40 homes (@ 75,000 Btu/hr per home), an indirect distribution design (incorporating central heat exchangers) results in a lower total cost than a direct design (in which the geothermal fluid is delivered directly to the customer). This arises from the fact that central heat exchangers and pumps, do to economics of scale, are less expensive than individual components at each customer.

Branch service lines on the customer's property, are a significant cost item. Of the three principal piping installation methods available, preinsulated copper, field insulated copper and preinsulated flexible polyethylene (PEX), the field insulated copper has the lowest installed cost at approximately $\$ 23.00$ per lineal foot (for supply and return). For $60^{\prime}$ service lines (5000 $\mathrm{ft}^{2}$ lot with home in the center), the customer service line cost would amount to approximately $\$ 1400$. 
In order to answer the economics of serving an existing residential area with geothermal district heating, the costs identified in this report were combined with resource development costs to arrive at a total geothermal district heating system installed cost. Resource development costs were calculated using a spreadsheet previously developed by the Geo-Heat Center. A range of resource development costs were calculated based on a low case (1 - $500 \mathrm{ft}$ production well, no injection well) to a high case ( $2-2000$ production wells, 1 injection well). Combing the costs for the resource development with distribution and central plant costs discussed above resulted in a system cost range for the 256 house area of $\$ 920,000$ to $\$ 1,568,000$. Based on $8 \%$ financing, the debt service necessary to meet this capital cost ranged from $\$ 86,800$ to $\$ 148,000$ per year requiring a revenue per home of between $\$ 452$ to $\$ 771$ per year, assuming $75 \%$ customer penetration rate.

Current conventional heating costs (for space and domestic hot water) for the homes in the area ranges from a low of $\$ 439$ (50\% gas, $50 \%$ wood space heat/gas dhw) to a high of $\$ 1053$ (all electric) per year.

Based on these figures it appears that geothermal district heating in existing single-family residential area could be feasible in situations where:

- Propane, fuel oil and electricity (or combination of these fuels with wood) dominate the conventional heating used,

- $\quad$ Small lot sizes $\left(<5,000 \mathrm{ft}^{2}\right)$,

- Subdivisions where unpaved areas are available for installation of some or all of the distribution system, and

- Customer penetration rate is high ( $275 \%)$. 


\section{REFERENCES}

Lienau, P. and H. P. Ross, 1995. "Low-Temperature Resource Assessment Program," Geothermal Resources Council Transactions, Vol. 19, Geothermal Resources Council, Davis, CA.

Means, R. S., Co., 1996. Means Mechanical Cost Data - 1996, 19th Edition, R. S. Means Co., Inc. Kingston, MA.

Means, R. S., Co., 1995. Means Site Work and Landscape Cost Data - 1995, R. S. Means Co., Inc., Kingston, MA.

Rafferty, K., 1995. "A Spreadsheet for Geothermal Direct Use Cost Evaluation." Geo-Heat Center, Oregon Institute of Technology, Klamath Falls, OR.

Rafferty, K., 1992. Unpublished report to city of Klamath Falls regarding billing options for Michigan Street residences. Geo-Heat Center, Oregon Institute of Technology, Klamath Falls, OR.

Rafferty, K., 1990. "An Overview of U.S. Geothermal District Heating Systems," ASHRAE Transactions, Vol. 98, Part 2, American Society of Heating, Refrigerating and Air Conditioning Engineers.

Rafferty, K., 1990. "Should You Go Bare - The Feasibility of Uninsulated Piping - A Spreadsheet." Geo-Heat Center, Oregon Institute of Technology, Klamath Falls, OR.

Rafferty, K., 1989. "Geothermal District Piping - A Primer." Geo-Heat Center, Oregon Institute of Technology, Klamath Falls, OR.

Rafferty, K., 1989. "A Material and Equipment Review of Selected U.S. Geothermal District Heating Systems." Geo-Heat Center, Oregon Institute of Technology, Klamath Falls, OR. 